\title{
Impact of Climate Change on Water Availability and Food Security of Nepal
}

Roshan Kumar Mehta and Shree Chandra Shah
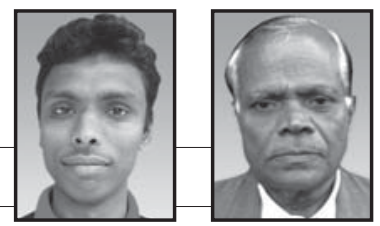

Roshan Kumar Mehta Shree Chandra Shah

\begin{abstract}
The increase in the concentration of greenhouse gases (GHGs) in the atmosphere is widely believed to be causing climate change. It affects agriculture, forestry, human health, biodiversity, and snow cover and aquatic life. Changes in climatic factors like temperature, solar radiation and precipitation have potential to influence agrobiodiversity and its production. An average of $0.04^{\circ} \mathrm{C} /$ year and $0.82 \mathrm{~mm} /$ year rise in annual average maximum temperature and precipitation respectively from 1975 to 2006 has been recorded in Nepal. Frequent droughts, rise in temperature, shortening of the monsoon season with high intensity rainfall, severe floods, landslides and mixed effects on agricultural biodiversity have been experienced in Nepal due to climatic changes. A survey done in the Chitwan District reveals that lowering of the groundwater table decreases production and that farmers are attracted to grow less water consuming crops during water scarce season. The groundwater table in the study area has lowered nearly one meter from that of 15 years ago as experienced by the farmers. Traditional varieties of rice have been replaced in the last 10 years by modern varieties, and by agricultural crops which demand more water for cultivation. The application of groundwater for irrigation has increased the cost of production and caused severe negative impacts on marginal crop production and agro-biodiversity. It is timely that suitable adaptive measures are identified in order to make Nepalese agriculture more resistant to the adverse impacts of climate change, especially those caused by erratic weather patterns such as the ones experienced recently.
\end{abstract}

Key words: Agriculture, climate change, water availability, food security, Nepal

\section{Objectives}

The objectives of the paper are to discuss the impacts of and present recommendations to adapt to climate change in the areas of:

- groundwater and general water availability,

- agricultural production, and

- food security in Nepal.

\section{W}

duction

Tater is indispensable for life, but its availability at a sustainable quantity and quality is threatened by many factors, of which climate plays a leading role. The Intergovernmental Panel on Climate Change (IPCC 2001) defines climate as "the average weather in terms of the mean and its variability over a certain time-span and a certain area." Statistically significant variations of the mean state of the climate or of its variability lasting for decades or longer, is referred to as climate change.

Climate change is a phenomenon arising due to emissions of greenhouse gases from fuel combustion, deforestation, urbanization and industrialization (Upreti 1999) resulting in variations in solar energy, temperature and precipitation. It largely affects water resources, agriculture, coastal regions, freshwater habitats, vegetation and forests, snow cover and melting of ice. It results in geological processes such as landslides, desertification and floods, and have long-term effects on food security as well as human health. Water vapor, carbon dioxide $\left(\mathrm{CO}_{2}\right)$, methane $\left(\mathrm{CH}_{4}\right)$, nitrous oxide $\left(\mathrm{N}_{2} \mathrm{O}\right)$ and Chlorofluorocarbons (CFCs) are the gases that play an important role in the greenhouse effect. GHGs $\mathrm{CO}_{2}, \mathrm{CH}_{4}$ and $\mathrm{N}_{2} \mathrm{O}$ are the three major gases which contribute to about $88 \%$ of the global warming (Houghton, Meira Filho et al 1996).

It is anticipated that groundwater systems, as part of the hydrological cycle, will be affected by changes in recharge (which encompasses changes in precipitation and evapo-transpiration), potentially by changes in the nature of the interactions between the groundwater and surface water systems, and changes in use related to irrigation. Therefore, quantifying the impact of climate change on groundwater resources requires not only reliable assessment of changes in the major climatic variables, but also accurate estimation of groundwater recharge.

The World Food Summit in 1996 defined food security as "the situation when all people at all times have access to sufficient, safe and nutritious food to meet their dietary needs and food preferences for an active and healthy life." Nepal's economy depends on agriculture. The total area of Nepal is $147,181 \mathrm{~km}^{2}$ divided in mountains (35\%), hills (42\%) and Terai lowlands (23\%). A total of 3,091,000 ha $\left(30910 \mathrm{~km}^{2)}\right.$ area is cultivated for agriculture, and it accounts for $33 \%$ of the gross domestic product (GDP) (World Bank 2010). The Terai region is the main granary of food for the country and is susceptible to disasters, including flash floods and glacial lake outburst floods (GLOFs). Agricultural production in the Terai is affected by melting snow in the mountains leading to floods, and to droughts. Agricultural productivity is gradually decreasing due to the increased incidence of floods, diseases and insect-pests caused by climate change. Food production is also affected by lack of input (seed, fertilizer, irrigation and plant protection measures) on time and the climatic condition which affect the sowing time of crops. The 2008/09 year food production situation is shown in Table 1.

\section{Material and Methods}

The potential impacts of climate change on water resources have long been recognized although there has been comparatively little research relating to groundwater. The principle focus of climate change research with regard to groundwater has been on quantifying the likely direct 


\begin{tabular}{|l|r|r|r|r|r|r|}
\hline $\begin{array}{c}\text { Ecological } \\
\text { Region }\end{array}$ & $\begin{array}{c}\text { Net Edible } \\
\text { Production }\end{array}$ & Requirement & Balance & Balance \% & SSR (\%) & PCEA (kg) \\
\hline Mountain & 296,510 & 365,701 & $-69,191$ & $-18.92 \%$ & 81 & 155 \\
\hline Hill & $2,080,755$ & $2,426,366$ & $-45,611$ & $-14 \%$ & 86 & 172 \\
\hline Terai & $2,783,135$ & $2,501,249$ & 281,888 & $11.26 \%$ & 111 & 201 \\
\hline Nepal & $5,160,400$ & $5,293,316$ & $-132,914$ & $-2.51 \%$ & 97 & 186 \\
\hline
\end{tabular}

Table 1. Food Balance Situation (Metric ton) (2008/09). (Source: SINA 2009)

SSR $=$ Self Sufficiency Ratio (Percent), PCEA = Per Capita Edible Availability

impacts of changing precipitation and temperature patterns. There are two main parameters that could have a significant impact on groundwater levels: recharge and river stage/discharge.

To assess the impact on the groundwater system and the food security, a study was conducted in Nepal's Inner Terai district of Chitwan. A survey was conducted in seven village development committees (VDCs) of the district. The questionnaire survey was done by the block sampling method by selecting a focal person of each ward of the VDC; i.e., nine spots of each VDC were selected and one spot from the VDC main office of seven VDCs, which totals 70 samples. The respondents showed that the water table has drawn down in last 15 years.

\section{Results and Discussions}

\section{Impact of climate change on water availability}

The Koshi, Narayani, Karnali and Mahakali are four major rivers flowing from the Himalayas, and are the main sources of drainage while also contributing to irrigation water. Agricultural sectors, mainly, crops, livestock and horticulture, largely depend on the given water sources in the country: rivers, lakes, ponds and groundwater. Variability in climate and weather are a major reason for changes in moisture availability in the soil. The rapid evapo-transpiration due to increase in temperature, will demand more water to reduce drought. Water availability governs the physiologically active period and crop production. Climate fluctuations affect human behavior, which in turn may alter the water supply-demand balance in different regions of the world (Kulshrestha, Kos and Priyajhinskaya 1996).

The study from the selected area shows that average depth of groundwater table from the surface was five meter and in recent year it was more than six meters. The most shallow water table was found in Patihani VDC at five meters, while the deepest was in Shivnagar VDC at seven

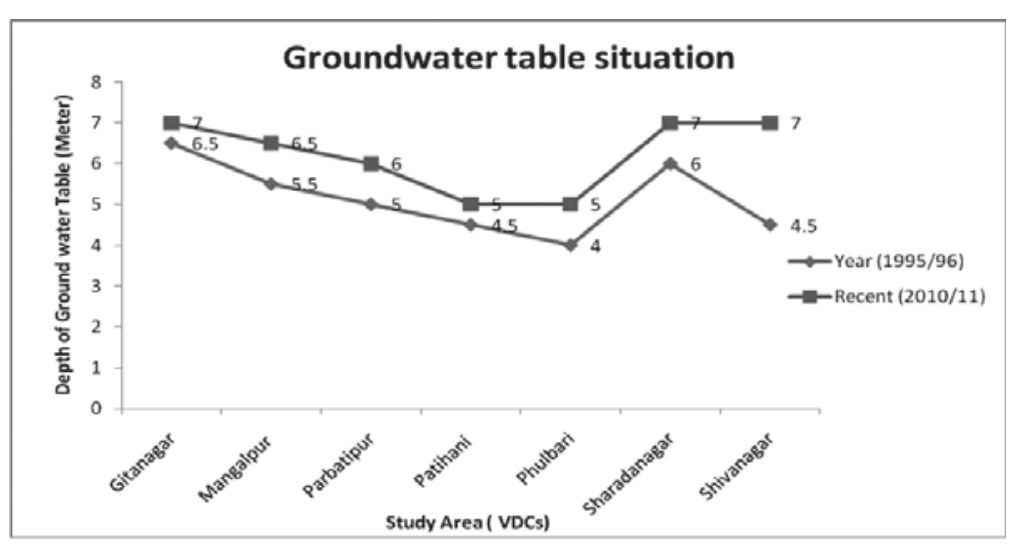

Figure 1. Groundwater Situation of the Study Area. meters. The groundwater table of the study area has decreased by more than one meter over a period of 15 years. The decrease in groundwater is due to excessive pumping of water through deep boring for irrigation. Rising temperatures increase demand for water that is supplied from groundwater. Intensive rainfall is more responsible for flood and erosion of nutrient than groundwater recharge.

\section{Impact of climate change on agricultural production}

Weather is an atmospheric condition from minutes to weeks which has an important impact on agriculture production(ICIMOD/UNEP 2007). Nepal is disaster prone and sensitive to the consequences of climate change. More than $80 \%$ of precipitation occurs in the monsoon season, June to September. Increase in temperature and advent of erratic rainfall directly affects agriculture and food supply through their effects on crops. The temperature differences are most pronounced during the winter season and least after the summer monsoon begins (Shrestha 2000). Agriculture is sensitive to short-term changes in weather that affect the production of crops.

Climate change also causes disruption in the normal weather pattern changing the intensity and the duration of the monsoon. A number of impacts due to climate change are expected in the agriculture system of Nepal because the major part of it is rain fed, and there are very complex linkages of its components to climatic parameters. Because of location (agro-ecology) specific changes speculated in climatic parameters (specifically temperature and precipitation) and climate change impacts are likely to vary from one ecological region to another. Changes in form, intensity, timing and amount of precipitation affect crop production and natural resource balance including sustenance of agro biodiversity through crop water supply. According to Figure 4, the average precipitation rate is increasing at $0.82 \mathrm{~mm} / \mathrm{year}$, but the shortening of the monsoon season and high intensity rainfall creates more flooding than infiltration. The rainfall pattern also varies randomly; Nepal received about $1800 \mathrm{~mm}$ in 2002, while in 2005 and 2006 it decreased to $1300 \mathrm{~mm}$.

Similarly, a variety of impacts can be seen on crops and natural sustenance of crop wild relatives when temperature range exceeds optimum limits that vary with plant types. According to Figure 3 , the average annual maximum temperature has increased at the rate of $0.04^{\circ} \mathrm{C} /$ year from 1975 to 2006. The rise in temperature directly increases the consumptive water use of crops. The crops need an increased irrigation period and frequency to meet the water demand. Temperature rises combined with changes in precipitation characteristics can worsen the situations by favoring bacterial and fungal diseases. Moreover, impacts of climate extremities can be critical from the point of view of crops growth and production when they 
coincide with critical crop stages such as flowering.

Paddy, the most important stable food crop in the country that requires abundant water for growth and development, is easily affected by considerable reduction in yield due to delayed monsoon and resulting delay in transplanting. High precipitation washes away the mineral nutrients of the soil thus decreasing productivity. An increased $\mathrm{CO}_{2}$ concentration in the atmosphere and changes in temperature and precipitation due to climate change may have some positive impacts in crop growth and production. An elevated $\mathrm{CO}_{2}$ and increased temperature combined with high precipitation can enhance crops' growth performance. Under elevated $\mathrm{CO}_{2}$ levels, rice yields have decreased in the Terai plain but have increased in the foothills of the Terai and in the mountains. In contrast, however, it shows no effect on maize yield (NARC 2007).

In the global context, Harrison and Aiyer noted the potential for $\mathrm{CH}_{4}$ release from rice fields as early as 1913 (Neue 1993). Concentration of the $\mathrm{CH}_{4}$ gas in the atmosphere is presently increasing at the rate of $3 \%$ per year. It is predicted that by the year 2100 methane levels may rise by 3.0 to $4.0 \mathrm{ppm}$, with resultant significant effect on climate change. The World Data Center of Greenhouse gases has reported that recent global abundance of $\mathrm{CO}_{2}, \mathrm{CH}_{4}$ and $\mathrm{N}_{2} \mathrm{O}$ is $377.1 \mathrm{ppm}, 1.783 \mathrm{ppm}$ and $318.6 \mathrm{ppb}$, respectively (World Climate News 2006).

Deforestation and the loss of agro-biodiversity leads to a decrease in soil organic matter so the desertification has begun. More chemical fertilizer is needed to achieve the same production. The cost of production has increased due to irrigation and chemical fertilizer costs, challenging food price controls. The lack of purchasing power is a real and threatening challenge for the food security of Nepal. Indigenous varieties of major cereals have been lost from the farmers' community. Crop-biodiversity is decreasing at

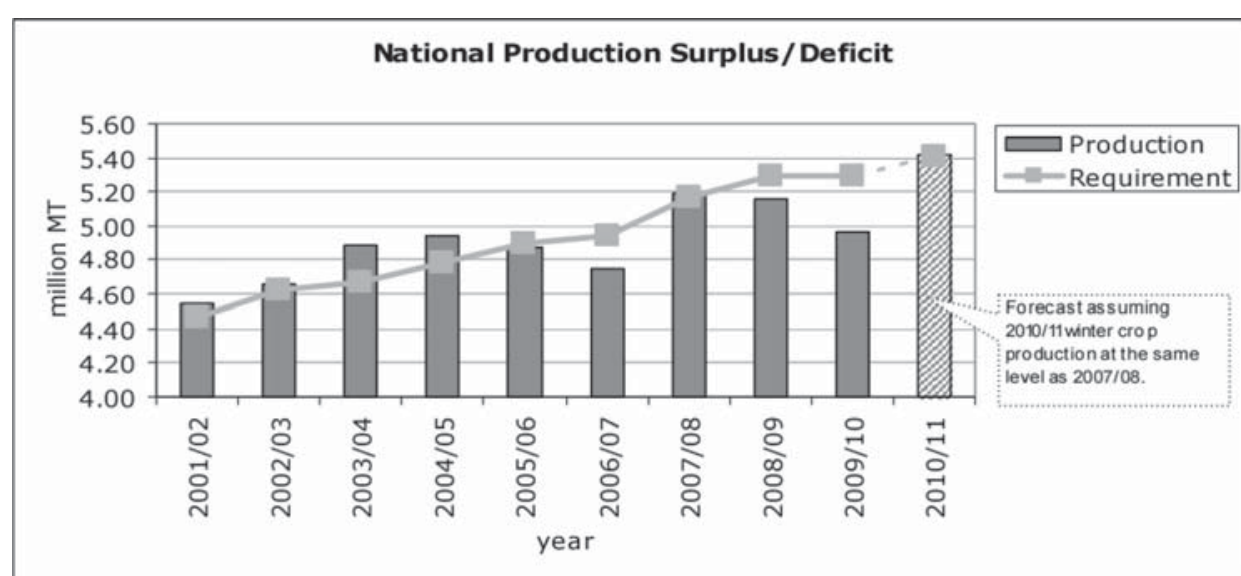

Figure 2. National Edible Cereal Production Surplus/Deficit for the Past Ten Years. (Source: MOAC/WFP 2011)
All Nepal Temperature Trend

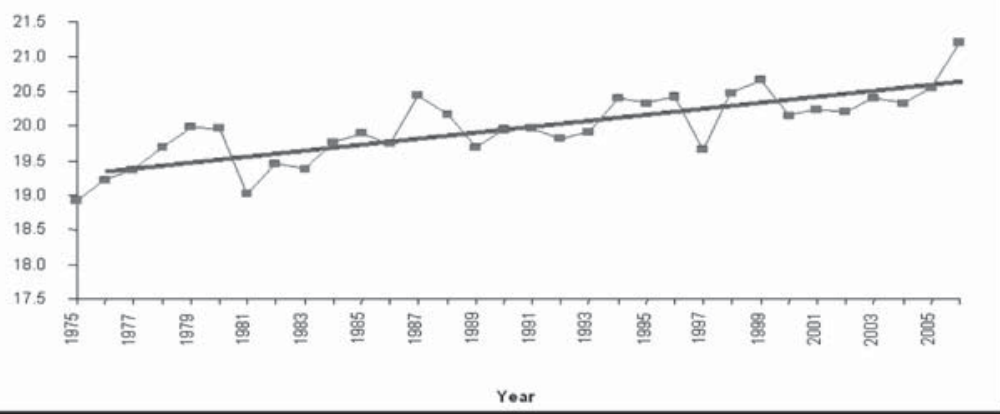

Figure 3. Trend of Average Annual Max. Temperature of Nepal (19752006). (Source: Baidya and Karmacharya 2007)

All Nepal monsoon rainfall trend (1971-2006)

$y=0.82 x+1551.89$

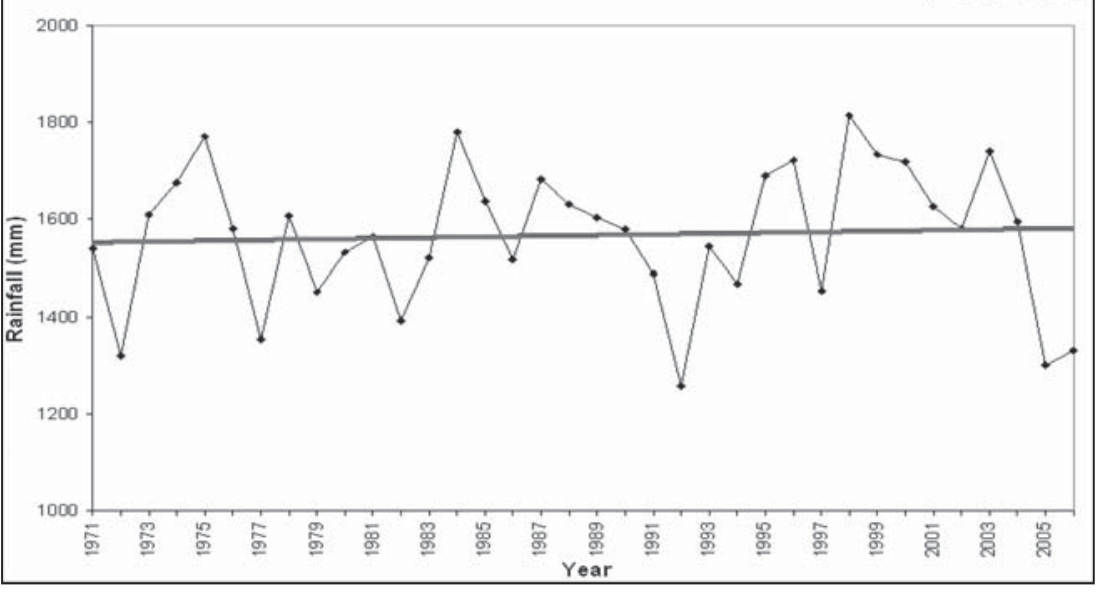

Figure 4. Trend of Total Precipitation. (Source: Baidya and Karmacharya 2007)

an alarming rate. Local varieties, which were very tolerant to adverse climate condition and good in taste, have disappeared from the farmers' fields. Modern varieties of major crops have fully covered the farms, which need larger quantities of chemical fertilizer and irrigation water in order to produce yields similar to indigenous varieties (Malla 2008).

The soil environment has been badly affected by chemical and pesticide application for agricultural production. The groundwater table is deeper now than 15 years ago, which is a major challenge for irrigation as most of the farmers are using deep boring for farm irrigation. In the last 10 years, traditional varieties of rice (Aapjhutte, Achhame Masino, Adhikhola Jernali, Jethobudho, Kasmire, Makasi, Manabhog, Manamuri, Masino Pahalman, and Pokhreli Masino) have been replaced by modern varieties requiring more water (Masuli, Sabitri, Radha 4 Laxmi, Makawanpur 1, Radha 7, Jhapali Masuli, and Kanchhi Masuli) (MoAC 2011). 


\section{Impact of climate change on food security}

Globally more than one billion people (i.e., one sixth of the world population) live on less than US $\$ 1$ per day, and they are the ones to suffer most from chronic hunger and malnutrition (RAPFW 2006; WSFS 2009). South Asia has about 423 million people, the highest number living in absolute poverty and making up about $40 \%$ of world's hungry people. The region holds about $23 \%$ of the world population but hardly commands $2 \%$ of global income, suggesting the highest concentration of poverty and food insecurity in the world (FAO/SAARC 2008).

South Asia is primarily an agricultural region having around $52 \%$ population dependent on agriculture, accounting for an average of $22 \%$ share of gross domestic production (GDP) in the region. One of the major reasons underlying poverty and food insecurity in the region is low agricultural productivity, the implications of which include poor food availability and lack of purchasing power by people to buy sufficient food. One most important way to ensure food security is, therefore, to boost agricultural productivity, increasing food supply, enhancing income and overall access to adequate food (Haq 2003).

Food availability in Nepal is mainly a function of agricultural performance. Although the contribution of agriculture to gross domestic product (GDP) has been declining over time, it is still the largest economic sector employing $65 \%$ of the economically active population and contributing to $33 \%$ of the GDP. The major food grains in Nepal are paddy, maize, wheat, millet and barley, which together account for $77 \%$ of cultivated area in 2008/09. Among the cereals, paddy covers about $46 \%$ of the total cereal area, producing around $56 \%$ of total cereal outputs followed by maize (24\%), wheat (17\%), millet (3.61\%), and barley (0.29\%).

Figure 2 shows that national production is far below the demand from 2008/09 to the present. Table 1 indicates that the Himalayas and mountains of Nepal are food deficit areas, whereas the Terai lowland has sufficient food. The national demand also needs nearly $3 \%$ more production to meet the increasing food demand. Access to adequate food depends upon income available to household and food prices. It also depends on land holding patterns, income distribution and employment opportunities. Access to food may also depend on infrastructures, transport, connectivity and food policy adopted by the government.

It is therefore said that food insecurity is more of a distribution issue than a production issue. Food insecurity has its roots to poverty that leads to poor health, low productivity, low income, food shortage and hunger. The Terai region is the basket of food grains but many districts in this region are also food deficit, which shows that food security is a very challenging issue for Nepal. Climate change may aggravate this issue through negative impacts created by rising temperatures and altered weather patterns.

\section{Strategies for improving water availability, agricultural production and Food Security in Nepal}

The government of Nepal must take long term vision in order to meet the national demand for food security.

Organic and biodynamic farming systems have soils of higher biological, physical, and in many cases chemical quality than that of conventional counterparts. When productivity, in terms of inputs applied and outputs obtained, and social costs of conventional farming are considered, the organic alternative has been found to be significantly economical. Integrated Pest Management (IPM) is a knowledge intensive approach dichotomous to conventional chemical intensive approach that best serves the farmer. Rainwater harvesting is a simple and low cost technique that involves the capture and storage of rainwater from roofs and ground catchments for domestic, agricultural, industrial and environmental purposes. Water harvesting has many advantages in rapidly growing cities and under future climate change scenarios. Rainwater harvesting can enhance the water availability at any specified location and time, increase groundwater levels and improve groundwater ecosystems. Elevated rainwater tanks save energy as groundwater has to be pumped from underground.

Some specific steps for ensuring food security in Nepal

- Use more disease and pest tolerant varieties and promotion of local and indigenous crop cultivars.

- Adjustment of sowing dates based on rainfall patterns.

- Alter the use of fertilizer/pesticide, ensure good quality seeds and planting materials and implement food production \& self reliance program in food deficit remote districts.

- Integrated nutrient management and soil fertility improvement.

- Practice crop rotation and conserve cropbiodiversity, encourage horticultural crops, agroforestry, herbs and non-timber forest products (NTFPs), encourage nitrogen fixing and legume crops with promotion the use of organic fertilizer, manure bio pesticide, resource conservation technology.

- Crop diversification, multiple cropping and catch crops.

- Village level gene seed grain banks are one of the most important methods used to provide seed, food and nutritional security and conserve agrobiodiversity; such decentralized system where villagers themselves plan, manage and undertake all stage of food production, storage, distribution and management are more sustainable in providing food security at local level.

- Community-based processes like Participatory Plant Breeding (PPB) and Participatory Varietals Purification and Selection (PVS) are emerging practices, along with Integrated Pest Management (IPM) and Integrated Nutrient Management (INM), to optimize productivity.

- Forests play an important role in mitigating climate change; the IPCC recognizes that sustainable forestry offers reduction in emissions from deforestation and forest degradation (REDD), forestation, increasing sequestration in existing forests, supplying biomass for bio-energy and providing wood as a substitute for more energy intensive products should be promoted. 
- Rain water harvesting and promotion of high water use efficiency techniques of irrigation are essential to meet the demand.

\section{Conclusion}

There is no doubt that the impacts of climate change on water availability and food security of Nepal are very severe. Crop-biodiversity, which was adaptable to local adverse impacts as well as changing climates, has decreased. Climatic events like floods and droughts, along with the rise in temperature and incidence of new diseases, as well as insect-pests, are great threats to agricultural production. The decreasing availability of irrigation water and the lowering groundwater table are water related challenges to agricultural production. The poor financial status of Nepalese farmers makes it difficult for them to cope with the negative impacts on agriculture due to changing climates.

Farmers have experienced lowering of the water table by one meter over the last 15 years. Deep and shallow boring methods are increasingly used to harvest groundwater. Farmers setup village level gene seed grain banks to conserve and use local landraces. The groundwater along with drip irrigation methods may be useful for crop production. Rainwater harvesting at the field level may be a tool to solve irrigation problem and enhance food security in community.

Roshan Kumar Mehta is student at the Institute of Agriculture and Animal Science, (Tribhuwan University), Rampur, Chitwan, Nepal. He also served as President for Rural Youth Forum, Nepal. He was awarded 3rd prize in the Open Online Photography Competition organised by Nepal National Water Week-2010 Committee. He has participated in many national and international events. Corresponding address: roshankmehta@gmail.com

Shree Chandra Shah, PhD, is a professor of Soil Science in the Institute of Agriculture and Animal Science (IAAS), Chitwan, Nepal, since 1999. He has published many research papers in the fields of soil science and agronomy in national and international journals.

\section{References}

Baidya S. K. and J. Karmacharya, 2007, 'Climate change and its impact on Nepalese agriculture', Journal of Agriculture and Environment 9:62-71.

FAO/SAARC, 2008, Final Report: Regional Strategies and Program for Food Security in SAARC Member States, Bangkok: FAO Regional Office for Asia and Pacific and Kathmandu SAARC Secretariat.

Haq, Mahbub ul, 2003, 2003, Human Development in South Asia 2002, Karachi, Pakistan: Oxford University Press.

Houghton, J.T., L.G. Meira Filho, B.A. Callander, N. Harris, A. Kattenberg, and K. Maskell (eds.), 1996,
Climate Change 1995: The Science of Climate Change, Contribution of Working Group I to the Second Assessment Report of the Intergovernmental Panel on Climate Change, Cambridge UK and New York: Cambridge University Press.

ICIMOD/UNEP, 2007, Global Climate Change and Retreat of Himalayan Glaciers in China, India, Bhutan and Nepal, Kathmandu: International Centre for Integrated Mountain Development (ICIMOD) and U.N. Environment Program (UNEP).

IPCC, 2001, Climate Change 2001: The Scientific Basis, Contribution of Working Group I to the Third Assessment Report of the Intergovernmental Panel on Climate Change (IPCC), Cambridge, UK and New York: Cambridge University Press; URL: www.grida. no/climate/ipcc_tar/wg / index.htm.

Kulshrestha, S.N., Z. Kos and V. Priyajhinskaya, 1996, 'Implications of climate change for future water demand', pp.106-167 in Kaczmarek, Z., K.M. Strezepek, L. Somlody and V. Priyajhinskaya (eds.), Water Resources Management in the Face of Climatic/Hydrologic Uncertainties, Laxenburg, the Netherlands: International Institute for Applied Systems Analysis.

Malla, G., 2008, 'Climate change and its impact on Nepalese agriculture', Journal of Agriculture and Environment 9:62-71.

MOAC/WFP, 2011, Crop Situation Update: A Joint Assessment of 2010 Summer Crops and Outlook for 2011 Winter Crops, Kathmandu: Ministry of Agriculture and Cooperatives and FAO World Food Program.

MOE, 2009, Climate Change National Policy (Draft), Kathmandu: Ministry of Environment.

NARC, 2007, Climate Change and Agriculture in Nepal, Kathmandu: Nepal Agriculture Research Council, Environment Unit.

Neue, H., 1993. 'Methane emission from rice fields: Wetland rice fields may make a major contribution to global warming', BioScience 43(7):466-73.

Roles of Agriculture Project Final Workshop (6-7 December 2006), the Roles of Agriculture in Developing Countries: The Policy Implications, FAO Headquarter, Rome, Italy

Shishiso H. and R. Bajracharya, April 2010, Nepal Economic Update, World Bank Nepal.

Shrestha, M.L., 2000, 'International variation of summer monsoon rainfall over Nepal and its relation to Southern Oscillation Index', Meteorology and Atmospheric Physics 75:21-28.

Upreti, D.C., 1999, Rising Atmospheric CO and Crop Response. SASCOM Scientific Report, pp 1-8.

World Climate News, 2006. Homing in on rising sealevels. June 29, 2006.

WSFS, 2009, Feeding the World, Eradicating Hunger (WSFS 2009/INF/2), November 16-18, 2009, Rome: World Summit on Food Security. 